UDC 577.151.6:576.311.348:576.52

\title{
Surface-exposed actin binds plasminogen on the membrane of agonist-activated platelets: a flow cytometry study
}

\author{
A. A. Tykhomyrov, D. D. Zhernossekov, T. V. Grinenko \\ Palladin Institute of Biochemistry, NAS of Ukraine \\ 9, Leontovycha Str., Kyiv, Ukraine, 01601 \\ artem_tykhomyrov@ukr.net
}

\begin{abstract}
Aim. To elucidate whether actin exposed on the surface of agonist-activated platelets is responsible for plasminogen binding. Methods. Human washed platelets were obtained by gel-filtration on Sepharose-2B. The levels of exposed actin on the outer surface of plasma membrane of intact and thrombin- or collagen-stimulated platelets were monitored by flow cytometry. The binding of plasminogen fluorescent conjugate (Pg-FITC) with platelets treated with anti-actin antibody or non-immune IgG (control) was analyzed cytometrically. Results. Thrombin or collagen exposure resulted in the dose-dependent actin expression on the surface of stimulated platelets. Pre-treatment of stimulated platelets with specific anti-actin antibodies was shown to significantly prevent the binding of Pg-FITC with the platelet surface. Conclusion. The results of the present study indicate that actin exposed on the platelet surface at the agonistinduced activation is involved in the plasminogen binding.
\end{abstract}

Ke y w o r d s: platelets, surface-exposed actin, plasminogen, flow cytometry.

\section{Introduction}

Platelets play a key role in hemostatic process and regulate inflammatory and proliferative events through releasing adhesive and coagulation proteins, growth factors and angiogenesis inhibitors. The platelet activation triggers cytoskeletal rearrangement that provides morphology changes, exocytosis, adhesion, aggregation, and retraction [1]. Activation also stimulates the expression of subcellular structures and novel proteins not detectable in the quiescent state on the outer surface of plasma membrane. There are several lines of independent evidences indicating exposition of some cytoskeletal proteins on the surface of agonist-stimulated platelets $[2,3]$. Actin, a principal component of platelet cytoskeleton microfilaments, is among them [4]. However, the molecular mechanisms of actin translocation on the activated membrane and "external" functions of this major cytoskeletal protein are still obscure.

(C) 2017 A. A. Tykhomyrov et al.; Published by the Institute of Molecular Biology and Genetics, NAS of Ukraine on behalf of Biopolymers and Cell. This is an Open Access article distributed under the terms of the Creative Commons Attribution License (http://creativecommons.org/licenses/by/4.0/), which permits unrestricted reuse, distribution, and reproduction in any medium, provided the original work is properly cited 
Plasminogen, a 92 kDa single-chain glycoprotein, is an inactive proform of proteinase plasmin that dissolves fibrin in blood clots, acts as a proteolytic factor in tissue remodeling, tumor invasion, and inflammation [5]. It has been well-documented that the binding of plasminogen to platelets is augmented by thrombin stimulation, suggesting exposure of additional binding sites on the activated membrane [6]. It has been demonstrated during the experiments with pure proteins and with the use of cell culture models that plasminogen and actin interact with high extent of affinity. According to the data obtained by various research groups, $\mathrm{K}_{\mathrm{d}}$ for the plasminogen-actin complex is about $70-140 \mathrm{nM}$ [7]. These values are consistent with those describing the high-affinity interaction of plasminogen with actin exposed on PC12 cells [8]. Previously, actin has been identified on the surface of various normal and transformed cell types [see 9, 10, 11 for summary]. For example, externally exposed actin has been observed on the sperm head, where it takes part in the process of membrane modification during sperm capacitation and initiation of acrosomal reaction [12]. Moreover, actin located on the outer side of the plasma membrane has been found as a binding site for plasminogen. The Surface-expressed $\beta / \gamma$ actin isoforms of catecholaminegic cells are directly involved in the plasminogen activation, and resultant plasmin promotes the formation of bioregulatory inhibitory peptides, thus modulating neurotransmitter release [13]. Finally, $\beta$-actin expressed on the surface of some tumor cell lines (PC-3, HT1080, MDA-MB321), mediates plasmin autoproteolysis resulting in the angiostatin AS 1-4.5 formation [7, 14]. It is logical to suppose that if the amounts of cellsurface actin are related to its possible functional activity, the surface actin expression may provide a subtle mechanism for regulation of plasminogen binding. It should be further tested what kind of functional activities actin-bound plasminogen expresses on the platelet surface: is it involved in platelet signaling or does it undergo proteolytic fragmentation, resulting in the biologically active fragments (angiostatins) formation? It is important to establish due to the fact that the interaction of plasminogen/plasmin system and platelets is considered as a crossroad between hemostasis, tissue reparation and remodeling, wound healing, cell invasion, angiogenesis, and inflammation. Therefore, this issue raises many questions, the dissection of which may shed light on a putative role of the actinplasminogen interactions on platelets in norm and their contribution to different pathological processes.

We have previously developed and used flow cytometry assay to measure actin exposition on the platelet surface and observed that dynamic changes of this parameter directly depend on the agonist (thrombin) concentration [4]. The aim of this study is to test the hypothesis that the surface-exposed platelet actin can be involved in plasminogen binding, and thus to provide further evidence for of functional significance of platelet actin in such an unexpected location.

\section{Materials and Methods}

\section{Chemicals}

All chemicals and reagents were from Sigma Aldrich (USA) except for those specified. 


\section{Plasminogen purification and plasmi- nogen-fluorescein isothiocyanate (Pg- FITC) conjugation}

Native (Glu-) plasminogen was purified from fresh blood plasma of healthy donors by means of affine chromatography on lysine-sepharose, as described elsewhere [15]. Electrophoretically pure plasminogen was labeled with fluorescein isothiocyanate (FITC) to obtain fluorescent plasminogen conjugate (Pg-FITC), as previously described [16]. Neither plasminogen nor PgFITC displays spontaneous proteolytic activity, as measured using the S2251 chromogenic assay. Research protocols were approved by the Ethical Committee of Palladin Institute of Biochemistry of NASU ( $3^{\text {rd }}$ November, 2014, protocol no. 10).

\section{Platelets}

Washed platelets were obtained from human platelet-rich plasma by gel-filtration on Sepharose 2B as described elsewhere [17]. Informed consent was obtained from all donors $(n=3)$ in accordance with the Declaration of Helsinki, and ethical approval for the study was provided by the local ethics committee as mentioned above. To assess platelet viability and functional activity, platelet aggregation was measured by optical aggregometry (aggregometer Solar AT-02, Republic of Belarus). All assays were performed within $60-80 \mathrm{~min}$ after platelet collection. Thrombin at final concentrations $0.1,0.5$ or 1.0 unit $\mathrm{NIH} / \mathrm{ml}$ and collagen (Tekhnologia Standard, Russian Federation) at final concentrations $0.125 \mathrm{mg} /$ $\mathrm{ml}, 0.6 \mathrm{mg} / \mathrm{ml}$ or $1.25 \mathrm{mg} / \mathrm{ml}$ were used to stimulate platelets $\left(5 \times 10^{6}\right.$ platelets per sample). Platelets were incubated with agonists for 5 min at $37^{\circ} \mathrm{C}$. The same amount of untreated (resting) platelets was used as a control.

\section{Flow cytometry}

Flow cytometry assay was used as a sensitive and direct method for detection of actin surface expression and monitoring Pg-FITC binding with platelet surface. Platelet activation was stopped with $1 \%$ paraformaldehyde in sodium phosphate buffered saline (PBS), $\mathrm{pH} 7.4$, for $20 \mathrm{~min}$ at room temperature, to prevent internalization of surface antigens and antibodies. Fixed platelets were washed with sodium-citrate (3.8\%)-PBS and sodium-citrate (3.8\%)PBS containing $1 \%$ BSA. Anti-actin antibody and anti-rabbit FITC-IgG were mixed in PBS in 1:80 and 1:200 dilutions, respectively (according to manufacturer recommendations) and left for $30 \mathrm{~min}$ at $37^{\circ} \mathrm{C}$. Then, platelets were incubated with antibody mixture for $30 \mathrm{~min}$ at $4{ }^{\circ} \mathrm{C}$. Platelets incubated only with secondary FITC-conjugated antibody were used as a control for non-specific IgG binding (spontaneous, or background fluorescence).

In this study, we prevented interaction of platelet-surface actin with $\mathrm{Pg}$ as a ligand by an anti-actin-antibody. Fixed platelets were treated with anti-actin antibodies for $30 \mathrm{~min}$ at room temperature, washed with PBS and labelled with Pg-FITC (in saturated concentration $100 \mu \mathrm{g} / \mathrm{ml}$ ) in the same conditions. One sample of platelets was treated with non-immune IgG as an isotype control. All procedures with labelled proteins were performed in the dark place to avoid photobleaching. After staining, platelets were washed from unbound antibodies or Pg-FITC twice with PBS by centrifugation at $1000 \mathrm{~g}$ for $3 \mathrm{~min}$ at $4{ }^{\circ} \mathrm{C}$. Then, platelets were resuspended in $1 \mathrm{ml}$ of PBS, and the percentage of FITC-positive platelets and intensity of specific FITC fluorescence were monitored using of Coulter 
A
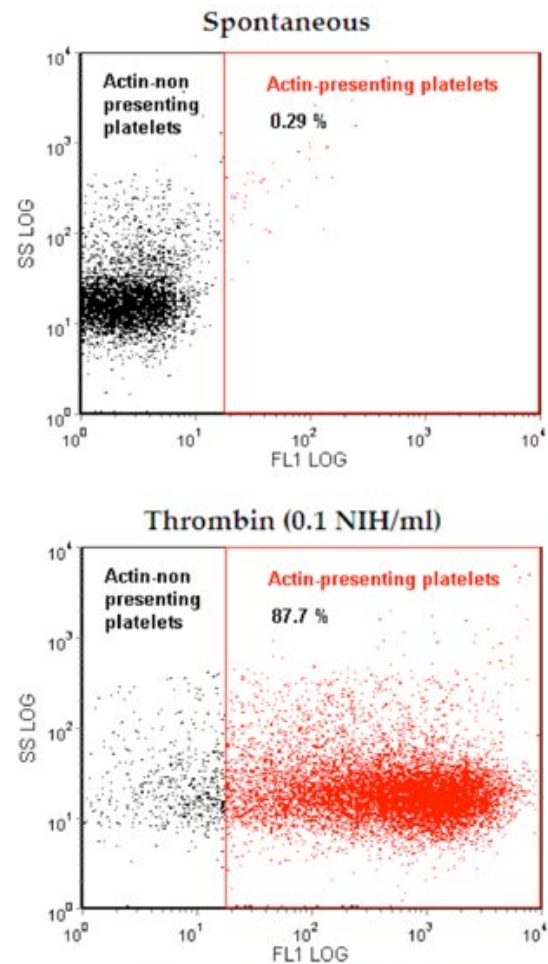

Thrombin $(0.5 \mathrm{NIH} / \mathrm{ml})$

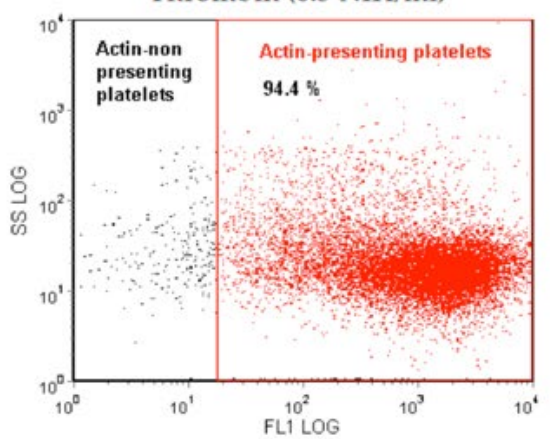

Thrombin $(1.0 \mathrm{NIH} / \mathrm{ml})$

flow cytometry histograms of anti-actin antibody binding to platelets activated by thrombin or collagen, respectively; $D$ - values of FITC-signal intensities showing agonist concentration-dependent expression of platelet surface actin (the differences between each group vs. resting control are all statistically significant with $P$ level no higher than 0.01).

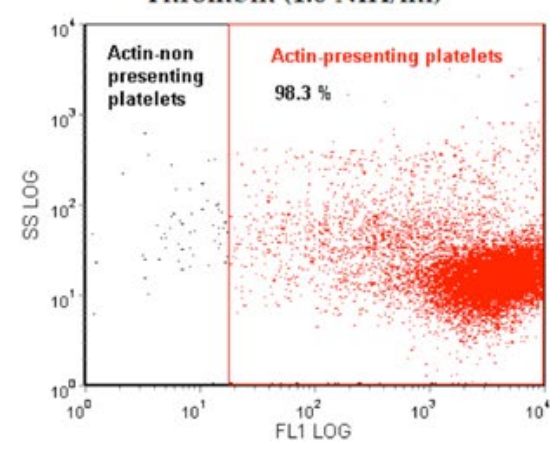

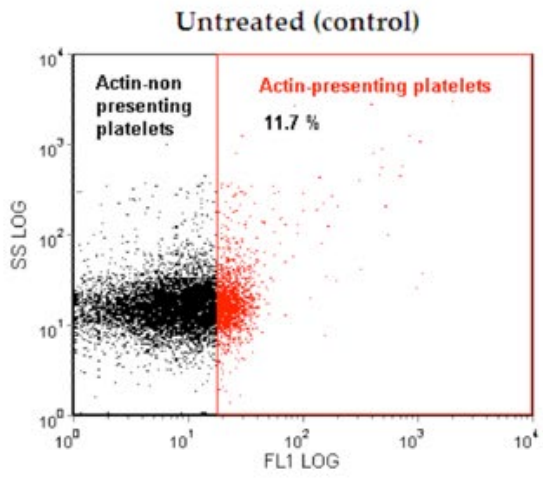
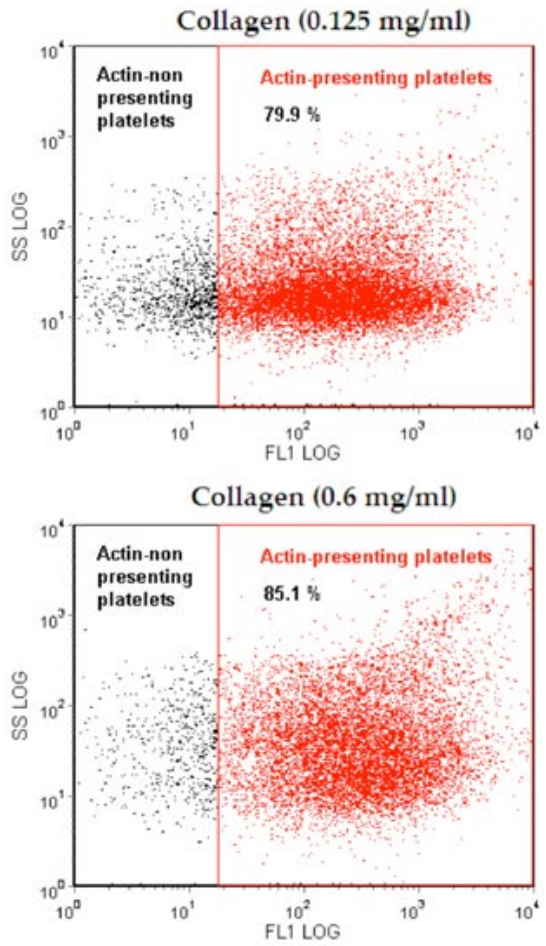
B

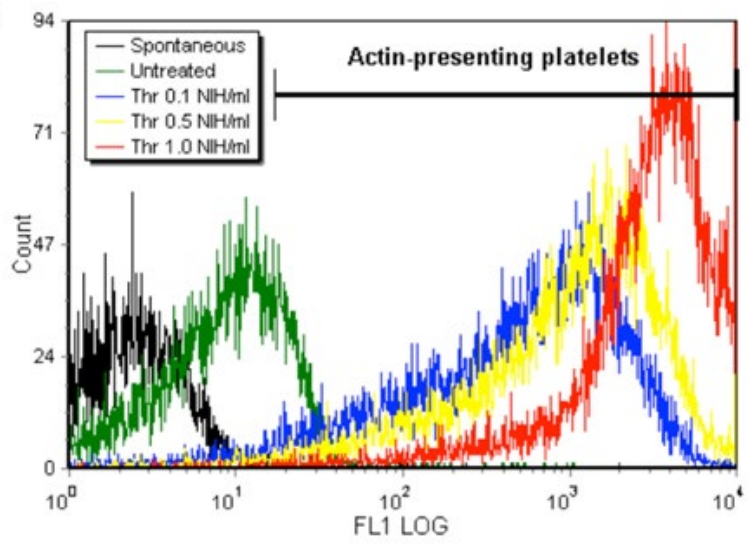

C
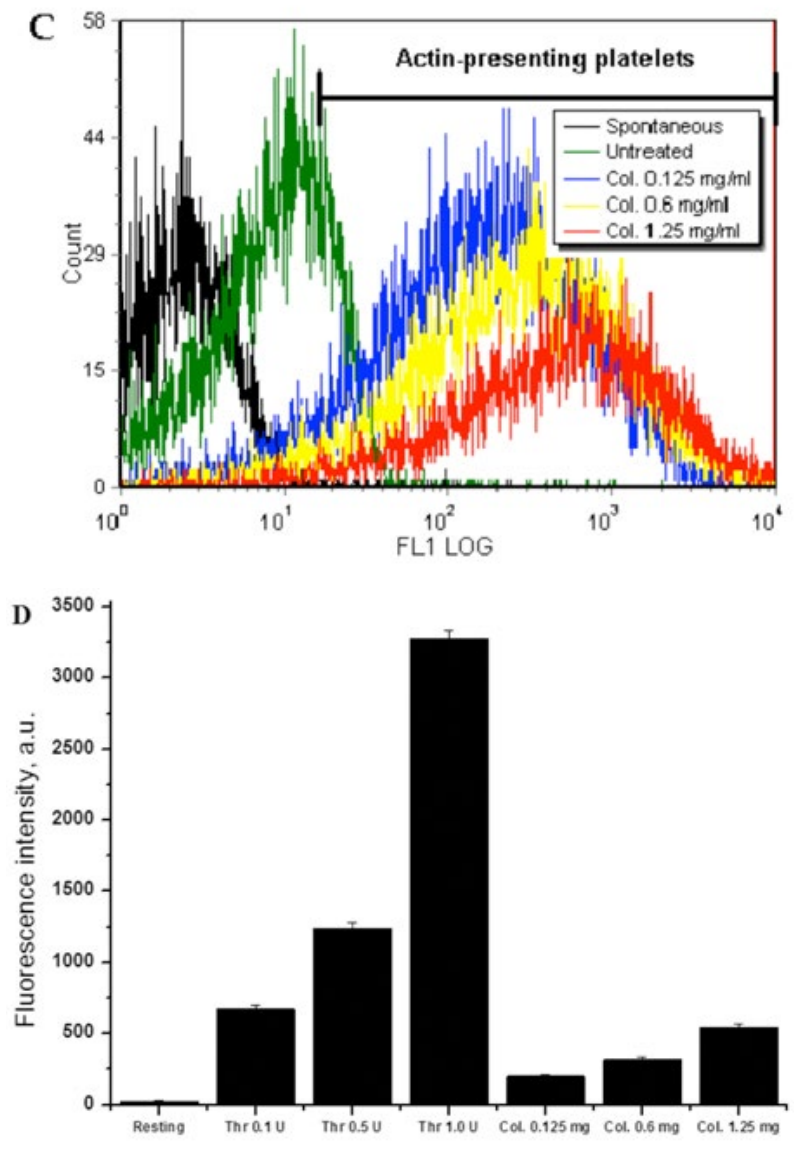

Epics XL device (Beckman Coulter, USA) via FL1 channel (515-535 nm). Population of untreated platelets was chosen for threshold value setting. Surface actin- or plasminogenpositive platelet populations were gated separately from the specific fluorescence-negative platelet population on the basis of sideward scattering (SSC). For control samples and thrombin-activated platelets, 15000 events were analysed, whereas for collagen-activated platelets at least 3000 events were analyzed due to high ability of collagen to cause platelet aggregation. Then the FITC-stained events found in the positive gate were expressed as the percentage of definition platelets. The measurement of cytometric parameters in each group of platelets was carried out in duplicate, and the mean value was calculated based on the values obtained from all donors. Intensity values of FITC fluorescence were expressed as arbitrary units. The results were analyzed and presented using "FCS Express V3" software system (De Novo Software, USA).

\section{Statistical analysis}

The results were expressed as mean \pm standard error of mean $(\mathrm{M} \pm \mathrm{m})$ or as medians for nonnormal distributions. The statistics were performed with the use of Student's $t$-test. Differences between parameters studied in each group were considered to be significant at $P$ less than 0.05 .

\section{Results and Discussion}

This study was performed to determine for the first time the role of surface-exposed actin in plasminogen binding by platelets. Earlier, we have performed flow cytometry assay to determine if thrombin-activated platelets are able to expose actin on their surface [4]. Here, we extend that study and established the platelets, activated by thrombin or other potent natural 
agonist, collagen, to represent actin-positive outer membrane. The results of cytometry sorting of platelets, presented in Fig. 1A, indicate an increase in percentage of the specific fluorescence actin-positive platelets in response to the agonist action. If the samples of resting platelets contained up to $12 \%$ of actin-presented species, the platelets after submaximal ( 0.1 unit $\mathrm{NIH} / \mathrm{ml}$ thrombin) stimulation represented $88 \%$ of actin-positive population. The percentage of actin-positive platelets reaches up to maximal value 94 and $98 \%$ after incubation with 0.5 or 1.0 units $\mathrm{NIH} / \mathrm{ml}$ of thrombin, respectively. The mean number of actin-presented platelets raised from 80 to $90 \%$ after stimulation with increasing collagen concentration (from $0.125 \mathrm{mg} / \mathrm{ml}$ to $1.25 \mathrm{mg}$ / $\mathrm{ml})$. It is seen from Fig. $1 \mathrm{~B}$ and $\mathrm{C}$ that thrombin, used in the indicated concentrations, induced more intense actin surface expression compared to collagen. Measurements of fluorescence signal values revealed a strong agonist dose-dependent character of the actin exposition in platelets treated by thrombin in concentration of $0.1,0.5$ or 1.0 unit $\mathrm{NIH} / \mathrm{ml}$, which was respectively 30-, 54- and 143-fold higher in comparison with this level for untreated platelets (Fig. 1D). However, collagen stimulation caused a lesser extent of the actin exposition that maximally reached only 24 -fold increment in the case of application of the highest concentration $(1.25 \mathrm{mg} / \mathrm{ml})$. These differences between the thrombin- and collagen-induced actin expositions are probably related to the activation of distinct signal pathways responsible for cytoskeleton rearrangement in platelets.

In the present work, we unequivocally established that the agonist-induced exposi- tion of actin contributes to the plasminogen interaction with activated platelets. Interestingly, there is only limited population of resting platelets $(\sim 35 \%$ of total amount of platelets), which appeared to be able to bind plasminogen (Fig. 2A). In contrast, both thrombin and collagen in their maximal concentrations (1.0 U NIH/ml and $1.25 \mathrm{mg} / \mathrm{ml}$, respectively) dramatically increase the quantity of Pg-FITC-positive platelets (in average, 94.4 and $95.2 \%$, respectively). However, as shown by the intensity signal curve analysis, the plasminogen-binding ability of the collagen-exposed platelets appeared to be much weaker than that for of thrombin-activated counterparts (Fig. 2 B and C). Notably, actin blockade by inhibitory antibodies insignificantly lowered the quantity of Pg-FITCbinding platelets. Thus, 93.8 and $84.9 \%$ of thrombin- or collagen-stimulated platelets, respectively, remained to be gated as FITCpositive events. However, the intensity signal from fluorescence conjugate bound to platelets decreased 4- and 2.5-fold in the cases of thrombin- or collagen-activated platelets, correspondently, Fig. 2D). These data mean that, apart from actin, other molecular targets also mediate the plasminogen interactions with the surface of activated platelets. It has been earlier reported that there are several molecules on the platelet surface, which ensure plasminogen binding, including integrins $(\alpha \mathrm{M} \beta 2, \alpha 5 \beta 1, \alpha \mathrm{V} \beta 3, \alpha \operatorname{IIb} \beta 3)$, fibrinogen, fibronectin, vitronectin, and laminin 18 .

The presence of cytoskeletal proteins on the cell surface has been reported in several other studies [19, 20]. However, the mechanisms of actin export on the cell surface are still obscure and it must be determined how actin, which 

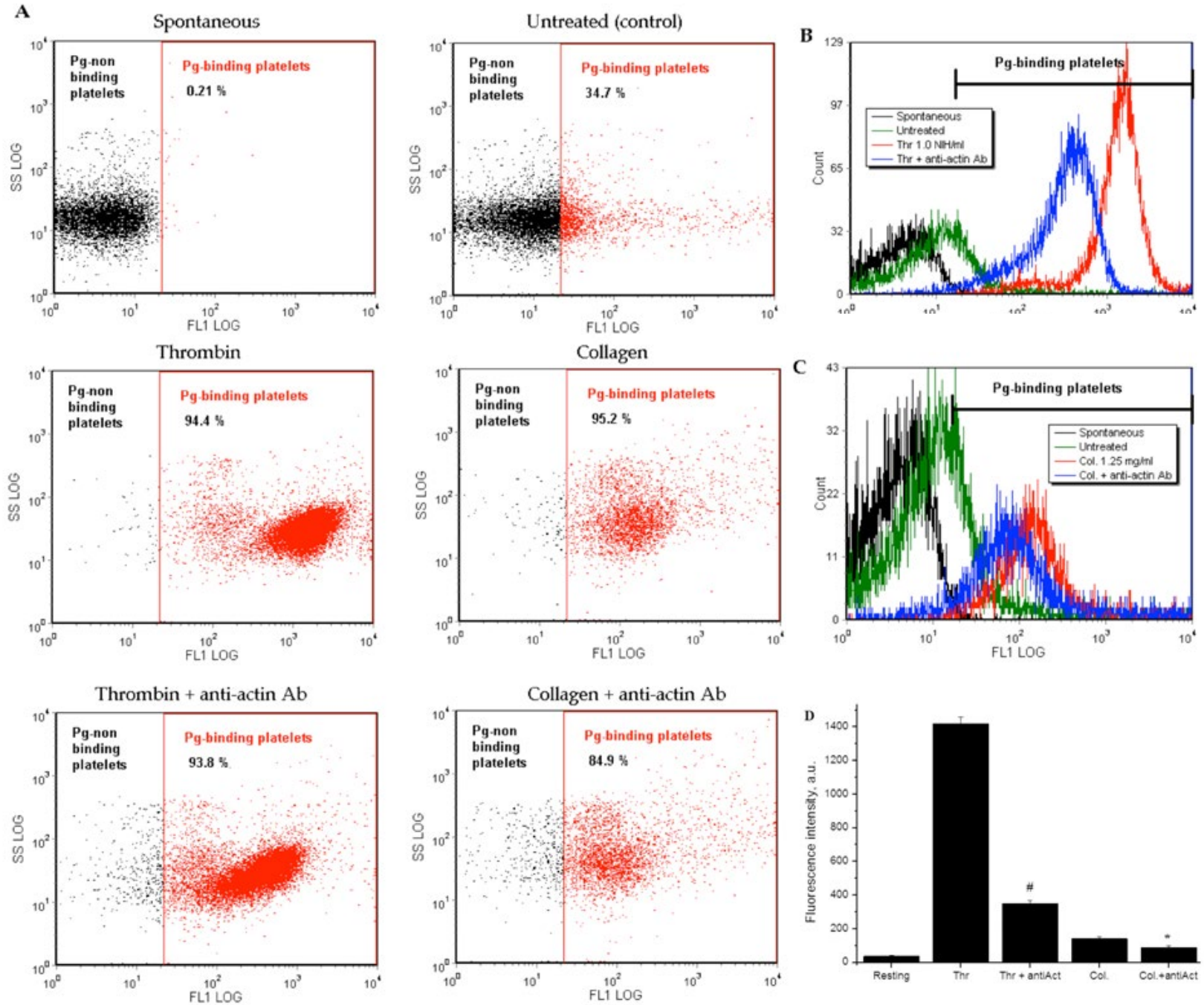

Fig. 2. Flow cytometric analysis of plasminogen binding with platelet surface: $A$ - representative dot plots indicating inhibitory effects of anti-actin antibodies on Pg-FITC binding by activated platelets; $\mathrm{B}$ and $C$ - representative flow cytometry histograms of Pg-FITC showing effects of pre-incubation with anti-actin antibodies on Pg-FITC fluorescence intensity pattern for platelets activated by thrombin or collagen, respectively; $D$ - values of signal intensities captured from FITC-positive platelets reflecting actin exposition in plasminogen binding ( $\#-P<0.001$ compared to thrombin-stimulated platelets, ${ }^{*}-P<0.05$ compared to collagen-exposed platelets).

lacks a classical signal sequence, moves to the cell surface and anchors to the plasma membrane. The authors [21] hypothesize the existence of specific mechanisms of actin transport in a complex with other proteins acting as carriers. For example, gelsolin being actinbinding protein is considered as a plausible candidate for the role of actin transporter because it can penetrate plasma due to a special signal peptide. Interestingly, the actin exposi- 
tion on the surface of some cancer cells is thought to be an attribute of their apoptotic changes, in which actin has been shown to play an important role. For instance, the cells of medullary breast carcinoma expose surface actin, which is accumulated in the region of apoptotic blebs [22]. It is well-known that the outside-in agonist-mediated signaling triggers actin cytoskeleton reorganization in platelets, and actin appearance on the platelet surface may be associated with the lipid rafts formation, membrane blebbing and exocytosis [23].

Actin is a $42 \mathrm{kDa}$ structurally highly conserved protein that occurs in all eukaryotic cells. Human platelet actin is represented by $\beta$ - and $\gamma$-isoforms, like in most non-muscle cells [25]. All isoforms are very similar at the sequence level and therefore all of them have been shown to bind plasminogen. The residues Lys61, 68 and 113, which are highly conservative and occur in all actin isoforms, are responsible for the plasminogen recognition. The residue Lys61 is the most important for the interaction with plasminogen because it is situated on the surface of the actin globule. Moreover, proteolytic processing at the C-terminus of actin resulting in the Lys373 exposure increases affinity of plasminogenactin binding and stimulates the cell-dependent plasminogen activation. In turn, the Lysbinding sites of plasminogen-plasmin kringle domains are involved in interaction with actin that can be inhibited by lysine and its analogues [10, 13].

Plasminogen as a plasmin precursor plays the major role in blood clot fibrinolysis. However, the current researches emphasize that plasminogen is involved in the regulation of the functional state of various cell types affecting different cellular components and signal pathways [25]. Our previous data have shown that the partially truncated Lys-form of plasminogen is able to interrupt the cytoskeleton remodelling, to affect the platelet degranulation, and to inhibit the agonist-induced platelet aggregation [26, 27]. Native (Glu-) plasminogen facilitates phosphatidylserine exposure on the surface of thrombin- or collagenactivated human platelets, thus promoting the formation of the platelet procoagulant surface [28]. Based on the data of Miles and others [13], it can be assumed that the cellsurface forms of actin may be involved in the pericellular plasminogen activation to plasmin as a binding site for proenzyme. The potential of platelets to enhance fibrinolysis by localizing plasminogen in the vicinity of a fibrin clot is in agreement with this observation [6]. Indeed, in the membrane-associated state, plasminogen acquires open conformation that is more readily converted into plasmin, which is able to further modulate the platelet response to thrombin and other aggregating agents that is influenced by its concentration [29]. Participation of surface-expressed actin in the plasminogen activation is additionally supported by the data demonstrating inhibitory effects of specific anti-actin antibodies on the cell-dependent plasminogen activation [13]. On the other hand, the activated platelets have been shown to secret and/or generate de novo proteolytically-derived plasminogen fragments, referred to as angiostatins, due to plasmin autoproteolysis. The mechanism of actinmediated angiostatin formation can represent the way, in which platelets may regulate reparative angiogenesis, thus counteracting proangiogenic stimuli [30]. 
Interestingly, actin is not the only cytoskeletal protein found in such an unusual location. It has been observed previously that the activated platelets presented one more cytoskeletal protein, vimentin, the major component of intermediate filaments. Vimentin exposed upon the platelet activation may serve to localize complexes [vitronectin - plasminogen activator inhibitor type I (PAI-I)] on the platelet surface. In summary, our research is one of the attempts performed to uncover the functional link existing between the platelet cytoskeleton and the plasminogen/plasmin system. We are currently undertaking studies to examine whether the interaction between actin and plasminogen on the platelet surface may, at least partially, contribute to the regulation of processes related to platelet physiology.

\section{Conclusions}

Herein, we provide for the first time direct evidence that surface-exposed actin is responsible for increased plasminogen binding with the surface of activated platelets. It can be summarized that the levels of surface-exposed actin may reflect the functional competence of platelets in plasminogen binding.

\section{Acknowledgement}

The authors are very grateful to Yana RokaMoiia and Svitlana Diordieva for their technical assistance.

\section{REFERENCES}

1. Yun SH, Sim EH, Goh RY, Park JI, Han JY. Platelet activation: the mechanisms and potential biomarkers. Biomed Res Int. 2016;2016:9060143.

2. Tschoepe D, Spangenberg P, Esser J, Schwippert B, Kehrel B, Roesen P, Gries FA. Flow-cytometric detection of surface membrane alterations and concomitant changes in the cytoskeletal actin status of activated platelets. Cytometry. 1990;11(5):652-6.

3. Podor TJ, Singh D, Chindemi P, Foulon DM, McKelvie R, Weitz JI, Austin R, Boudreau G, Davies R. Vimentin exposed on activated platelets and platelet microparticles localizes vitronectin and plasminogen activator inhibitor complexes on their surface. $J$ Biol Chem. 2002;277(9):7529-39.

4. Tykhomyrov AA. Dynamics of thrombin-induced exposition of actin on the platelet surface. Ukr Biochem J. 2014;86(5):74-81.

5. Castellino FJ, Ploplis VA. Structure and function of the plasminogen/plasmin system. Thromb Haemost. 2005;93(4):647-54.

6. Whyte CS, Swieringa F, Mastenbroek TG, Lionikiene AS, Lancé MD, van der Meijden PE, Heemskerk $J W$, Mutch NJ. Plasminogen associates with phosphatidylserine-exposing platelets and contributes to thrombus lysis under flow. Blood. 2015;125(16):2568-78.

7. Wang H, Doll JA, Jiang K, Cundiff DL, Czarnecki JS, Wilson M, Ridge KM, Soff GA. Differential binding of plasminogen, plasmin, and angiostatin 4.5 to cell surface beta-actin: implications for cancer-mediated angiogenesis. Cancer Res. 2006;66(14):7211-5.

8. Miles LA, Hawley SB, Parmer RJ. Chromaffin cell plasminogen receptors. Ann N Y Acad Sci. 2002; 971:454-9.

9. Sudakov NP, Klimenkov IV, Byvaltsev VA, Nikiforov $S B$, Konstantinov YM. Extracellular actin in health and disease. Biochemistry (Mosc). 2017;82(1):1-12.

10. Tykhomyrov $A A$. Interaction of actin with plasminogen/plasmin system: mechanisms and physiological role. Biopolym Cell. 2012;28(6):413-23.

11. Smalheiser NR. Proteins in unexpected locations. Mol Biol Cell. 1996;7(7):1003-14.

12. Liu DY, Clarke GN, Baker HW. Exposure of actin on the surface of the human sperm head during in vitro culture relates to sperm morphology, capacitation and zona binding. Hum Reprod. 2005;20(4):9991005.

13. Miles LA, Andronicos NM, Baik N, Parmer RJ. Cell-surface actin binds plasminogen and modulates neurotransmitter release from catecholaminergic cells. $J$. Neurosci. 2006;26(50):13017-24. 
14. Wang H, Schultz R, Hong J, Cundiff DL, Jiang K, Soff GA. Cell surface-dependent generation of angiostatin4.5. Cancer Res. 2004;64(1):162-8.

15. Deutsch DG, Mertz ET. Plasminogen: purification from human plasma by affinity chromatography. Science. 1970;170(3962):1095-6.

16. Magalhães V, Andrade EB, Alves J, Ribeiro A, Kim KS, Lima M, Trieu-Cuot P, Ferreira P. Group B streptococcus hijacks the host plasminogen system to promote brain endothelial cell invasion. PLoS One. 2013; 8(5):63244.

17. Schoenfeld H, Muhm M, Doepfmer U, Exadaktylos $A$, Radtke $H$. Platelet activity in washed platelet concentrates. Anesth. Analg. 2004; 99(1): 17-20.

18. Takada Y. Potential role of kringle-integrin interaction in plasmin and uPA actions (a hypothesis). J Biomed Biotechnol. 2012;2012:136302.

19. Dudani AK, Ben-Tchavtchavadze M, Porter S, Tackaberry E. Angiostatin and plasminogen share binding to endothelial cell surface actin. Biochem Cell Biol. 2005;83(1):28-35.

20. Sanders S.K., Craig S.W. A lymphocyte cell surface molecule that is antigenically related to actin. J Immunol. 1983;131(1):370-7.

21. Li GH, Arora PD, Chen Y, McCulloch CA, Liu P. Multifunctional roles of gelsolin in health and diseases. Med Res Rev. 2012;32(5):999-1025.

22. Hansen MH, Nielsen HV, Ditzel HJ. Translocation of an intracellular antigen to the surface of medullary breast cancer cells early in apoptosis allows for an antigen-driven antibody response elicited by tumorinfiltrating B cells. J Immunol. 2002;169(5):2701-11.

23. Head BP, Patel HH, Insel PA. Interaction of membrane/lipid rafts with the cytoskeleton: impact on signaling and function: membrane/lipid rafts, mediators of cytoskeletal arrangement and cell signaling. Biochim Biophys Acta. 2014;1838(2):532-45.

24. Bearer EL, Prakash JM, Li Z. Actin dynamics in platelets. Int Rev Cytol. 2002;217:137-82.

25. Law RH, Abu-Ssaydeh D, Whisstock JC. New insights into the structure and function of the plasminogen/plasmin system. Curr Opin Struct Biol. 2013;23(6):836-41.

26. Tykhomyrov A, Zhernosiekov D, Roka-Moüia I, Diordiieva S, Hrynenko T. Effects of Lys-form of plas- minogen on platelet actin cytoskeleton. Fiziol $\mathrm{Zh}$. 2014;60(1):25-33.

27. Tykhomyrov A, Zhernosekov D, Roka-Moya Y, Diordieva $S$, Grinenko $T$. The effects of lys-plasminogen on human platelet secretion. Fiziol $\mathrm{Zh}$. 2015;61(6):26-34.

28. Zhernossekov D, Roka-Moiia Y, Tykhomyrov A, Guzyk M, Grinenko T. Glu- and Lys-forms of plasminogen differentially affect phosphatidylserine exposure on the platelet surface. Ukr Biochem J. 2017;89(special issue):102-10.

29. Miles LA, Castellino FJ, Gong Y. Critical role for conversion of glu-plasminogen to Lys-plasminogen for optimal stimulation of plasminogen activation on cell surfaces. Trends Cardiovasc Med. 2003;13(1):21-30.

30. Radziwon-Balicka A, Moncada de la Rosa C, Zielnik B, Doroszko A, Jurasz P. Temporal and pharmacological characterization of angiostatin release and generation by human platelets: implications for endothelial cell migration. PLoS One. 2013;8(3):e59281.

\section{Роль експонованого актину у зв'язуванні плазміногену на мембрані агоніст-активованих тромбоцитів: цитометричне дослідження}
А. О. Тихомиров, Д. Д. Жерносєков, Т. В. Гриненко

Мета. 3'ясувати здатність актину, що експонується на поверхні тромбоцитів, активованих різними агоністами, зв'язувати плазміноген. Методи. Відмиті тромбоцити людини отримували за допомогою гель-фільтрації на Сефарозі-2В. Кількісну оцінку експонування актину на зовнішній поверхні інтактних тромбоцитів та тромбоцитів, активованих тромбіном або колагеном, проводили із застосуванням протокової цитометрії. Зв'язування флуоресцентного кон'югату плазміногенFITC (Pg-FITC) з тромбоцитами, обробленими антитілами проти актину або неімунними IgG (контроль), аналізували цитометрично. Результати. Вплив тромбіну та колагену призводить до появи на зовнішньому боці плазматичної мембрани тромбоцитів актину, кількість якого залежала від концентрації агоністів. Попередня обробка активованих тромбоцитів специфічними антитілами проти актину значно запобігала зв'язуванню Pg-FITC з поверхнею тромбоцитів. 
Висновки. Результати представленого дослідження вказують на залучення експонованого актину до зв'язування плазміногену на поверхні тромбоцитів, стимульованими різними агоністами.

К л ю ч о в і с л о в а: тромбоцити, експонований актин, плазміноген, протокова цитометрія

\section{Роль экспонированного актина в связывании плазминогена на мембране агонист- активированных тромбоцитов: цитометрическое исследование}

А. А. Тихомиров, Д. Д. Жерносеков, Т. В. Гриненко

Цель. Выяснить способность актина, который экспонируется на поверхности тромбоцитов, активированных различными агонистами, связывать плазминоген. Методы. Отмытые тромбоциты человека получали с помощью гель-фильтрации на Сефарозе-2В. Количественную оценку экспонирования актина на внешней поверхности интактных тромбоцитов и тромбоцитов, активированных тромбином или коллагеном, прово- дили с использованием проточной цитометрии. Связывание флуоресцентного конъюгата плазминоген-FITC (Pg-FITC) с тромбоцитами, обработанными антителами против актина или неимунными IgG (контроль), анализировали цитометрически. Результаты. Влияние тромбина и коллагена приводило к появлению на внешней стороне плазматической мембраны тромбоцитов актина, количество которого зависело от концентрации агонистов. Предварительная обработка активированных тромбоцитов специфическими антителами против актина в значительной степени предотвращала связывание Pg-FITC с поверхностью тромбоцитов. Выводы. Результаты представленного исследования указывают на вовлечение экспонированного актина в связывание плазминогена на поверхности тромбоцитов, стимулированных различными агонистами.

К л юч е в ы е с л о в а: тромбоциты, экспонированный актин, плазминоген, проточная цитометрия

Received 24.04.2017 